\title{
Rotation and Cover Crop Effects on Soilborne Potato Diseases, Tuber Yield, and Soil Microbial Communities
}

\author{
Robert P. Larkin, Timothy S. Griffin, and C. Wayne Honeycutt, United States Department of Agriculture- \\ Agricultural Research Service, New England Plant, Soil, and Water Laboratory, Orono, ME 04469
}

\begin{abstract}
Larkin, R. P., Griffin, T. S., and Honeycutt, C. W. 2010. Rotation and cover crop effects on soilborne potato diseases, tuber yield, and soil microbial communities. Plant Dis. 94:1491-1502.

Seven different 2-year rotations, consisting of barley/clover, canola, green bean, millet/rapeseed, soybean, sweet corn, and potato, all followed by potato, were assessed over 10 years (19972006) in a long-term cropping system trial for their effects on the development of soilborne potato diseases, tuber yield, and soil microbial communities. These same rotations were also assessed with and without the addition of a fall cover crop of no-tilled winter rye (except for barley/clover, for which underseeded ryegrass was substituted for clover) over a 4-year period. Canola and rapeseed rotations consistently reduced the severity of Rhizoctonia canker, black scurf, and common scab (18 to $38 \%$ reduction), and canola rotations resulted in higher tuber yields than continuous potato or barley/clover (6.8 to $8.2 \%$ higher). Addition of the winter rye cover crop further reduced black scurf and common scab (average 12.5 and $7.2 \%$ reduction, respectively) across all rotations. The combined effect of a canola or rapeseed rotation and winter rye cover crop reduced disease severity by 35 to $41 \%$ for black scurf and 20 to $33 \%$ for common scab relative to continuous potato with no cover crop. Verticillium wilt became a prominent disease problem only after four full rotation cycles, with high disease levels in all plots; however, incidence was lowest in barley rotations. Barley/clover and rapeseed rotations resulted in the highest soil bacterial populations and microbial activity, and all rotations had distinct effects on soil microbial community characteristics. Addition of a cover crop also resulted in increases in bacterial populations and microbial activity and had significant effects on soil microbial characteristics, in addition to slightly improving tuber yield ( $4 \%$ increase). Thus, in addition to positive effects in reducing erosion and improving soil quality, effective crop rotations in conjunction with planting cover crops can provide improved control of soilborne diseases. However, this study also demonstrated limitations with 2-year rotations in general, because all rotations resulted in increasing levels of common scab and Verticillium wilt over time.
\end{abstract}

Crop rotations, in general, provide numerous benefits to crop production. They can help conserve, maintain, or replenish soil resources, including organic matter, nitrogen and other nutrient inputs, and physical and chemical properties $(2,31,42)$. Crop rotations have been associated with increased soil fertility, increased soil tilth and aggregate stability, improved soil water management, and reduced erosion $(2,22)$. Probably most importantly, for

Corresponding author: R. Larkin

E-mail: Bob.Larkin@ars.usda.gov

Current address of T. Griffin: Tufts University, Friedman School of Nutrition Science and Policy, Boston, MA 02111.

Mention of trade names or commercial products in this article is solely for the purpose of providing specific information and does not imply recommendation or endorsement by the United States Department of Agriculture.

Accepted for publication 29 August 2010.

doi:10.1094/PDIS-03-10-0172

This article is in the public domain and not copyrightable. It may be freely reprinted with customary crediting of the source. The American Phytopathological Society, 2010. potato as well as many other crops, rotations are essential to maintain crop productivity and reduce the build-up of soilborne plant pathogens and diseases, which can devastate crops grown in multiple consecutive years $(13,14,32)$.

Cover crops are defined as crops grown primarily to cover and protect the soil from erosion and nutrient losses between periods of crop production (55). Cover crops may provide multiple benefits to crop production, including reduction of erosion, addition of organic matter, improved soil structure and tilth, addition and recycling of nitrogen, and greater productivity, as well as the potential for improved management of weeds, pests, and diseases $(16,43,55,59,64)$.

Within potato (Solanum tuberosum L.) production systems, numerous soilborne diseases are persistent and cause recurrent problems, including reducing plant growth and vigor, lowering tuber quality, and reducing yield. Soilborne potato diseases of most concern in the northeastern United States and other potato-growing regions include Rhizoctonia canker and black scurf, caused by Rhizoctonia solani Kühn; common scab, caused by Streptomyces scabiei (Thaxter) Lambert \& Loria; pow- dery scab, caused by Spongospora subterranea (Wallr.) Lagerh. f. sp. subterranean J. A. Toml.; white mold, caused by Sclerotinia sclerotiorum (Lib.) de Bary; silver scurf, caused by Helminthosporium solani Durieu \& Mont.; pink rot, caused by Phytophthora erythroseptica Pethybr.; and Verticillium wilt, caused by Verticillium dahliae Kleb. Most of these diseases are difficult to control, and there are few effective control measures readily available. Any improvements in disease management possible through crop rotation and/or the use of cover crops would be a welcome addition to the available tools for reducing soilborne diseases and improving crop productivity.

Current production practices in the northeastern United States and many other potato production areas are based on a 2year rotation with a low-maintenance grain forage crop (such as barley or oat). Such 2year rotations with a variety of crops (alfalfa, oat, vetch, lupin, buckwheat, and ryegrass) have been observed to reduce the incidence or severity of some soilborne potato diseases relative to continuous potato $(27,29,60,68)$. However, longer rotation lengths of 3 or 4 years between potato crops have been shown to be more effective than 2-year rotations in controlling soilborne diseases $(11,25,26,52,53)$. Within the framework of the 2-year as well as the longer rotations, different rotation crops may provide very different effects, with some providing better management of soilborne diseases and crop productivity than others.

Crops in the Brassicaceae family, for example, which include broccoli, cabbage, cauliflower, turnip, radish, canola, rapeseed, and various mustards, produce sulfur compounds that break down to produce isothiocyanates that are toxic to many soil organisms as part of a process referred to as biofumigation (56). Use of these plants as rotation, cover, or green manure crops has been observed to reduce soilborne diseases or populations of fungal pathogens and nematodes $(6,36,45,57)$, and to improve soil characteristics and crop yield (48). Further studies have indicated that additional mechanisms, including specific changes in soil microbial communities unrelated to levels of toxic metabolites, are also important in the reduction of soilborne diseases by Brassica crops $(12,36,47)$.

Plants are a primary driver of changes in soil microbial communities, and many 
recent studies have documented the effects of crop rotations on microbial communities $(34,37,41,66)$. Biological diseasesuppression is a result of complex changes in soil microbial community characteristics. Because crop rotations, cover crops, and green manures can dramatically affect soil microbial communities $(18,50,62,65)$; the use of specific crops for their effects on soil microbial communities and the development of disease-suppressive soils is a viable approach to disease management, sometimes referred to as active management of soil microorganisms $(18,28,46,54$, $62,67)$. The goal of this approach is to manipulate, alter, or augment the microbial characteristics of the soil through various management practices that increase soil microbial activity, diversity, populations of plant-beneficial organisms, and antagonism toward pathogens, resulting in disease suppression. Unfortunately, relatively little is known regarding the specific populations, characteristics, interactions, and relationships among plants and soil microorganisms that result in disease suppressiveness. More information is needed to relate crop management effects on soil microbial communities and their relationship to soilborne diseases.

Although several studies have evaluated crop rotation effects on specific diseases or yield in potato cropping systems, few have extended assessments beyond the first or second rotation cycle in order to get a more complete picture of the cumulative or long-term effects $(26,52)$. Also, although cover crops are known to have some positive effects on soilborne diseases in general, there is little information available specifically regarding effects of cover crops on soilborne potato diseases, and even less that includes relative effects of both rotations and cover crops within the same study. In previous research, we reported on some of the effects of different rotation crops on soil microbial communities within the first few years of different 2-year rotations (34), and showed some of the impacts of these rotation crops on disease development and their potential relationship with soil microbial communities (37). In this research, we summarize some of the cumulative effects of different 2year crop rotations on the development of soilborne disease and tuber yield in fields over a 10-year period (four or five rotation cycles), and also assess the effects of each rotation with and without the addition of a fall cover crop on soilborne disease, tuber yield, and soil microbial communities.

\section{MATERIALS AND METHODS}

Field site and sampling. Research plots were established at a United States Department of Agriculture field site in Newport, $\mathrm{ME}\left(44^{\circ} 52^{\prime} \mathrm{N}, 69^{\circ} 17^{\prime} \mathrm{W}\right)$ in 1997 and 1998 for the purpose of developing a longterm site for study of specific 2-year cropping systems for potato production. Soil type at the site is a Nokomis sandy loam, a coarse-loamy, mixed, frigid, Typic Haplorthod. Experiments were set up as randomized complete block designs consisting of four replicate plots (24.4 by $3.7 \mathrm{~m}$ ) for each of seven 2-year rotations. Each rotation was assigned to specific designated plots and maintained on these plots throughout the study period. To accommodate the need for potato crop data each year, two identical field experiments (same experimental design and 2-year rotations) were established in separate but adjacent fields in 1997 and 1998, respectively (field 1 planted to rotation crops in 1997 and potato in 1998; field 2 planted to rotation crops in 1998 and potato in 1999, and so on). Thus, between the two fields, both potato and rotation crops were grown each year (field 1 in potato in even years and field 2 in potato in odd years). All data collection, evaluations, and analyses were conducted only in the potato crop years in each field.

Crops used in rotation with potato included canola (Brassica napus L.), green bean (Phaseolus vulgaris L.), millet (Panicum miliaceum L.), soybean (Glycine max L.), and sweet corn (Zea mays L.), in addition to the current industry standard rotation of barley (Hordeum vulgare L.) underseeded with red clover (Trifolium pratense L.) and a continuous potato (nonrotation) control. Tillage for all plots consisted of primary tillage in the spring with a chisel plow and then secondary tillage of one to two diskings prior to planting. Cut seed pieces of potato cv. Russet Burbank were planted by hand in each plot (four rows, $0.9 \mathrm{~m}$ between rows, with a $35-\mathrm{cm}$ spacing between plants, or approximately 276 seed pieces/plot ). Potato plots were fertilized with the equivalent of $\mathrm{N}$ at $224 \mathrm{~kg} \mathrm{ha}^{-1}$ and $\mathrm{P}_{2} \mathrm{O}_{5}$ and $\mathrm{K}_{2} \mathrm{O}$ at $249 \mathrm{~kg} \mathrm{ha}^{-1}$. In-season cultivation included one or two shallow passes with a cultivator and one pass with a hiller. Potato plots were also sprayed regularly throughout the growing season with alternating applications of mancozeb and chlorothalonil at recommended rates for the control of late blight. All other crops were managed using recommended production practices, including fertilizer rates and weed control measures for that particular crop. Pesticides were applied only during the potato phase of the rotations. In 2001, millet was replaced by rapeseed (B. napus 'Dwarf Essex') and rapeseed was used in all subsequent years. Rapeseed was grown for 2 months, then incorporated as a green manure. These rotations were maintained through 2006, for a total of 10 years (and five rotation cycles) in the first field (established in 1997), and 8 years (four rotation cycles) in the adjacent field (established in 1998).

In 2002, all plots were split in half (to 12.2 by $3.7 \mathrm{~m}$ ) to evaluate the additional effects of a fall cover crop of winter rye (Secale cereale L.) within each rotation.
Winter rye was planted over the stubble of previous crops with a no-till drill on half of each plot following fall harvest in both the rotation and potato phases of the 2-year rotation. None of the plots received any additional fall tillage. In the case of barley/clover, because a cover crop was already included in that rotation (clover underseeded with the barley), a different cover crop, ryegrass (Lolium multiflorum L.), was implemented as an alternative underseeded cover crop with barley. Experimental design was a split block, with rotation as the main plot and cover crop as the split treatment. Thus, from potato year 2003 on, in addition to comparisons among rotation crops, comparison of each crop with and without the addition of a fall cover crop was made. An additional assessment of fall ground cover was made to compare effects of the cover crops on reducing the amount of bare soil present during the fall months in each rotation. Fall ground cover was assessed approximately 4 weeks after planting of the fall cover crops following harvest. Ground cover was estimated using the line intercept method (49). A linear transect with 50 points was placed across the soil and residue; the number of points directly over bare soil was noted (remaining points were over either living or dead plant material). Four transects were used per plot, for a total of 200 points.

Soil samples were collected from each plot twice during the growing season, in the spring (preplant) and in the fall (postharvest). Soil samples consisted of eight soil cores ( 15 by $2 \mathrm{~cm}$ in diameter) taken from the middle two rows or the middle 2$\mathrm{m}$ section for crops with closer spacing and many rows. All eight cores were combined to make one composite soil sample per plot at each sampling date. Upon return from the field, soil samples were passed through a $3.35-\mathrm{mm}$ sieve to remove rocks and large organic debris. Samples were stored in plastic bags at $10^{\circ} \mathrm{C}$ and processed within 1 to 4 weeks after sampling. Soil microbial analyses were conducted on every soil sample, with three subsamples processed from each composite soil sample for most assays.

Soilborne potato disease and tuber yield. Beginning in the potato crop year 2000 , potato plants were monitored in the field for signs and symptoms of soilborne diseases, including Rhizoctonia canker, white mold, and Verticillium wilt. In August of each year, two potato hills were selected from rows 1 and 4 of each plot. Each hill contained multiple potato stems per plant. These were destructively sampled (hand dug) to more accurately assess Rhizoctonia canker incidence and severity (cankers on stems and stolons assessed individually). Severity was determined on each stem or stolon using a 0 -to-5 rating scale, with $0=$ no symptoms; $1=$ discoloration, slight lesion; 2 = substantial lesion 
and necrosis covering $<50 \%$ of stem or stolon diameter; $3=$ lesion covering $>50 \%$ stem or stolon diameter; $4=$ large lesion girdling stem $(100 \%$ ); and $5=$ stem (or stolon) girdled, plant (or stolon) dead. Severity values from multiple stems and stolons per plant were combined to produce an average severity value for each observation. If symptoms of early dying (wilt, chlorosis, defoliation, or premature senescence) were observed in the field, all plots were then visually assessed for the full extent of wilt symptoms (estimated as a percentage of the total plants per plot, or wilt incidence). At this time, plant (stem) samples were also collected from each plot, surface sterilized in $0.5 \% \mathrm{NaOCl}$, rinsed in sterile water, cut into sections, and plated on a semiselective Verticillium medium (30) for verification of vascular infection by $V$. dahliae.

In October of each year, potato tubers were harvested from rows 2 and 3 of each plot. From 1999 to 2002, a 12.2-m row section was harvested and, from 2003 to 2006, a total of 30.2-m of row was harvested from each plot. Tubers were washed and graded. Yield was evaluated as the total weight of tubers per hectare, and marketable weight as the total weight of tubers greater than $114 \mathrm{~g}$ each. The percentage of obviously malformed or misshapen tubers was determined from the weight of misshapen tubers relative to the total weight of all tubers harvested. A subset of the harvested tubers, consisting of at least 30 tubers of marketable weight, was rated for incidence and severity of soilborne tuber diseases after at least 1 month in storage at $10^{\circ} \mathrm{C}$. Tuber diseases rated included black scurf, common scab, powdery scab, and silver scurf. Disease severity for all tuber diseases was determined as the approximate percent surface coverage of the visible symptoms on each tuber. Because tuber diseases covering an area of approximately $2 \%$ or greater of the tuber surface affect marketability, $2 \%$ was considered the threshold for assessing economically important severity levels of these diseases.

Microbial community characteristics. Soil microbial populations. General populations of culturable soil microorganisms were determined by soil dilution plating on agar media. For each of three subsamples from each composite soil sample, $10 \mathrm{~g}$ of soil was weighed and added to $90 \mathrm{ml}$ of sterile $0.2 \%$ water agar, vigorously stirred for $5 \mathrm{~min}$, and serially diluted and plated on $0.1 \%$ tryptic soy agar for total bacterial counts, as well as on potato dextrose agar amended with $50 \mathrm{mg}$ of chlortetracycline and tergitol at $1 \mathrm{ml} \mathrm{liter}^{-1}$ for total fungal counts (39). Bacterial plates were incubated at $28^{\circ} \mathrm{C}$ for 3 days, and fungal plates at $25^{\circ} \mathrm{C}$ for 7 days, prior to enumeration of viable colonies.

Substrate utilization (SU) profiles. The capability of soil microbial communities to use a variety of sole carbon sources was assessed using Biolog GN2 plates (Biolog Inc., Hayward, CA) by a procedure adapted from Garland and Mills (19) as previously described by Larkin (34). One GN2 plate was prepared for each of two soil subsamples (10 $\mathrm{g}$ of soil serially diluted as described for microbial plate counts), with $150-\mu l$ aliquots of a final dilution of 1:5000 added to each of the 96 wells per plate. The plates were incubated at $22^{\circ} \mathrm{C}$ and optical density was determined on a plate reader at 590 and $760 \mathrm{~nm}$ after 72 and $96 \mathrm{~h}$ of incubation. Optical density readings were corrected for the control (blank) wells on each plate before data analyses. SU data were also analyzed for substrate richness (the number of substrates utilized) and substrate diversity (using Shannon's diversity index). Average well color development (AWCD), calculated as the average optical density across all wells per plate, was used as an indicator of general microbial activity (34).

Fatty acid methyl ester (FAME) profiles. Soil community fatty acid profiles were constructed from whole soil extractions of FAMEs according to a modification of the Microbial Identification System (MIS; MIDI, Inc., Newark, DE) standard protocol as described by Larkin (34). Extractions were conducted on each of three 4-g soil subsamples per plot. Each sample was saponified, mixed, heated, methylated, mixed, cooled, extracted, and washed as previously described (34). The organic phase was then transferred to a vial for subsequent analysis by gas chromatography using an automated procedure developed by MIDI, Inc. for an HP 6890 gas chromatograph (Hewlett-Packard, Wilmington, DE) with an HP Ultra-2 capillary column and flame ionization detector. The fatty acids were identified according to the Eukary method and naming table software developed for the MIS. The fatty acid nomenclature used is as follows: total number of carbon atoms $=$ number of double bonds, followed by the position of the double bond from the methyl end of the molecule. Cis and trans geometry are indicated by the suffixes c and t. Anteiso- and isobranching are indicated by the suffixes ant and iso. Only fatty acids which accounted for at least $0.25 \%$ of the total fatty acid content over all observations from any given sampling date were included in the analyses. This prevented fatty acids that were only sporadically detected or unreliably quantified from influencing the analyses $(4,34)$. In addition, dicarboxylic acids and fatty acids with a chain length of $>20$ carbons were not included in the analyses because these are generally not of microbial origin (69). With these criteria, analyses consisted of 40 to 45 unique fatty acids.

Data analyses. Soilborne disease, yield, and microbial population counts were analyzed by analysis of variance (ANOVA) with factorial treatment structure and interactions (randomized complete block design for main rotation effects, split-block design for cover and no-cover effects [2003 to 2006]). The SU and FAME data were analyzed by principal components analysis using the covariance matrix followed by multivariate ANOVA (21) and by canonical variates analysis, which serves to maximize differences among treatment groups (7). The SU data also were analyzed by analysis of covariance and adjusted least square means compared among rotations for substrate richness and diversity analyses. To account for the influence of AWCD on SU patterns, AWCD was used as a covariate in these analyses (23). Data from each potato crop year were analyzed separately, and then data from multiple years were also combined and analyzed together (with year as an additional factor and including all interactions) to evaluate cumulative and multiyear effects of the rotation and cover crops. Area under the disease progress curve (AUDPC) calculated for disease severity measurements over multiple years was also used as an assessment of rotation effects over time (8). Correlation analysis (Pearson's product-moment correlation) was used to assess associations among environmental factors (average monthly temperature and rainfall), disease ratings, and yield over multiple years. In addition, coefficients of variation were calculated to assess overall variability associated with yearly fluctuations in yield and soilborne disease compared with rotation effects within years. Significance was evaluated at $P<0.05$ for all tests. Mean separation was accomplished with Fisher's protected least significant difference test. All analyses were conducted using Statistical Analysis Systems (ver. 9.1; SAS Institute, Cary, NC), with the general linear models procedure used for all ANOVA analyses. Most assays consisted of three subsamples and four replications (blocks). All SU data presented are based on 72-h incubation readings.

\section{RESULTS}

Rotation crop effects on soilborne diseases. Over the course of the study, represented by the seven consecutive years (2000 to 2006) that in-depth assays of soilborne disease were conducted, significant differences among rotation crops in the development of soilborne diseases were consistently observed. The predominant soilborne diseases throughout the study were Rhizoctonia canker on the potato plants (stems and stolons) in the field, and black scurf and common scab on the harvested tubers. Silver scurf and powdery scab were observed at very low levels throughout the study (in $<0.2 \%$ of rated tubers) and did not occur at sufficient levels required to monitor and make comparisons among rotations. Overall, canola, 
rapeseed, sweet corn, and barley/clover as rotation crops reduced the severity of Rhizoctonia canker relative to the potato nonrotation control $(P=0.001)$. Canola and rapeseed rotations provided the greatest reduction, ranging from 15 to $45 \%$ in individual years and averaging 20 to $23 \%$ over all 7 years (Fig. 1A). Soybean and green bean rotations did not reduce canker severity. Canola and rapeseed rotations were also most effective in reducing black scurf on tubers. These rotations had lower scurf severity than most other rotations and reductions of 32 to $38 \%$ relative to the continuous potato control $(P=0.0002)$ (Fig. 1B). Similar reductions in the incidence (percentage of tubers showing symptoms) of black scurf were also noted $(P=0.0001$, data not shown $)$. In particular, canola and rapeseed rotations reduced the incidence of tubers showing economically important scurf levels ( $2 \%$ or greater surface area), from $57 \%$ in continuous potato to 29 and $32 \%$ (reductions of 44 to $49 \%$ ) in rapeseed and canola, respectively $(P=$ 0.001 ). Rotation effects on common scab were more modest than for black scurf but, overall, canola and rapeseed rotations reduced common scab severity by 18 to $21 \%$ relative to continuous potato $(P=0.009$; Fig. 1C). No other rotation crop resulted in consistent reduction of common scab. Although year as a factor was highly significant $(P=0.0001)$ for all soilborne diseases, the interaction between year and rotation was not significant for any disease parameter ( $P=0.078$ to 0.836 ).

Rotation effects on tuber yield. Averaged over all eight seasons during which yield data were taken, modest but signifi-

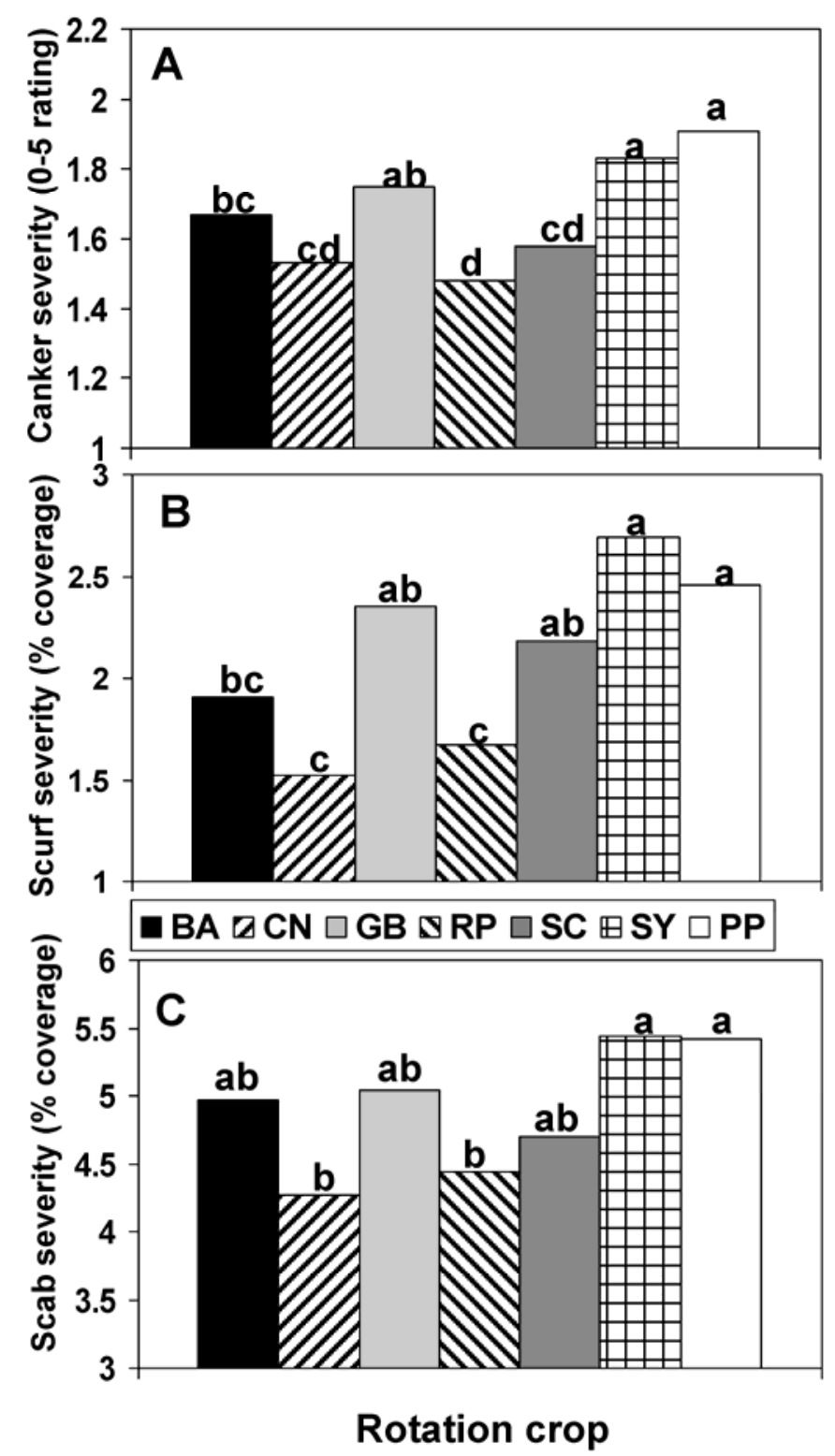

Fig. 1. Average effects of different rotation crops over a 7-year study period (2000 to 2006) on soilborne disease of potato plants and tubers from 2-year crop rotations for A, Rhizoctonia canker; $\mathbf{B}$, black scurf; and $\mathbf{C}$, common scab. $\mathrm{BA}=$ barley, $\mathrm{CN}=$ canola, $\mathrm{RP}=$ millet/rapeseed, $\mathrm{GB}=$ green bean, $\mathrm{SC}=$ sweet corn, $\mathrm{SY}=$ soybean, and $\mathrm{PP}=$ potato (control). Bars topped by the same letter are not significantly different according to Fisher's protected least significant difference test $(P<0.05)$. cant differences in total tuber yield were observed among rotations. Canola averaged $6.8 \%$ higher tuber yield than continuous potato, $8.2 \%$ higher than barley/clover, and $14.7 \%$ higher than green bean $(P=$ 0.011 ; Fig. 2A). Green bean rotations resulted in the lowest overall yields, significantly lower than canola, sweet corn, and soybean, averaging about $7 \%$ lower than continuous potato. No other rotation crop consistently affected tuber yield. Overall marketable yield based on size, as well as the distribution of different tuber size classes, varied among rotations and by year but was not consistently or significantly affected by rotation crop $(P=$ 0.478). However, tuber quality, as determined by misshapenness and tuber surface defects, was significantly affected by rotation crop. Averaged over all eight seasons, barley, rapeseed, soybean, and canola rotations all reduced the percentage of misshapen tubers by 40 to $55 \%(P=0.0001$; Fig. 2B). The interaction between year and rotation was not significant for any yield parameter $(P=0.067$ to 0.836$)$, with the exception of percent misshapen tubers $(P=$ 0.001).

Year-by-year effects and trends. Although average rotation effects represent the cumulative and consistent effects observed over several years, there can be much variability both within and among the different rotation crops from year to year, and yearly results also may isolate trends or impacts that may be obscured in multiyear averages. Yearly rotation effects on black scurf and common scab severity and tuber yield are graphically summarized in Figure 3. Black scurf was the primary soilborne disease observed in the early years of the study and remained at consistently high levels (severity of approximately 2.0 to $3.5 \%$ tuber coverage) in the potato, soybean, and green bean rotations throughout the study period (Fig. 3A). Significant rotation effects on black scurf severity were evident in all 7 years of disease assessment. Canola rotations resulted in significantly lower black scurf than continuous potato in 6 of the 7 years, and yearly severity values ranged from 0.5 to $2.0 \%$ (Fig. 3A). Although the originally planted rotation crop of millet had no significant effect on scurf in the years it preceded potato (2000 and 2001), once it was replaced in the rotation by rapeseed, significant reductions were observed in scurf severity, beginning in 2003 and continuing each subsequent year, averaging the lowest scurf severity of any rotation from 2003 on (yearly severity values between 0.65 and $1.67 \%$ ). The barley/clover rotation resulted in significant reductions in scurf severity for the first few seasons (through 2001), with severity values below $1.5 \%$, but then the disease increased in subsequent years to levels comparable with those of potato and soybean rotations (severity $>2 \%$ ). 
Another estimate of overall effects that takes into account all of the yearly fluctuations is AUDPC which, over all 8 years of black scurf data, indicated that rotation was highly significant $(P<0.0001)$. Rapeseed and canola rotations reduced AUDPC for black scurf severity by 28 and $30 \%$, respectively, compared with continuous potato, and by 35 to $36 \%$ relative to the soybean rotation. Barley/clover also reduced AUDPC by $16 \%$ relative to continuous potato. Sweet corn rotations showed the greatest year-to-year variability in black scurf severity (Fig. 3A), with much higher disease levels observed in even years $(2.4$ to $2.6 \%)$ than in odd years (1.6 to $1.9 \%$ ), indicating differences between the two experimental fields. No other rotation crop resulted in distinct differences related to the particular field experiment.

Common scab, in comparison, was not observed in the first few years of the study but steadily increased from barely detectable levels in $2002(<0.5 \%$ severity) to very high levels in 2005 (7 to $10 \%$ severity) in all rotations. However, there were still significant rotation effects on common scab noted in 3 of the 5 years that common scab was notable (Fig. 3B). In those years (2002, 2003, and 2005), rapeseed and canola rotations resulted in significant reductions in scab severity (20 to $54 \%$ reduction), and sweet corn and barley also reduced severity in 2003 (35 to 50\% reduction) relative to continuous potato. Canola and rapeseed rotations nominally reduced AUDPC values for common scab severity over all years by approximately $16 \%$ relative to continuous potato but overall differences among rotations were not statistically significant $(P=0.232)$.

Tuber yield was highly variable, both within and across rotations and from year to year, with yearly rotation yields ranging from 15 to $32 \mathrm{Mg} / \mathrm{ha}$ (and individual plot yields ranging from 9 to $38 \mathrm{Mg} / \mathrm{ha}$ ). Yearly fluctuations in yield, determined primarily by environmental conditions, were generally greater than rotation effects within years, as is evident in Figure 3C. The coefficient of variation (CV) related to yearly changes in yield was 16.0, more than double the average $\mathrm{CV}$ of 7.2 (range of 2.7 to 10.2) for rotation effects within each year. A further indication of the influence of yearly environmental conditions is that total yield was correlated with monthly summer rainfall totals, being most significant for the month of August $(r=0.62, P<$ $0.0001)$. Yield was also negatively correlated with average August temperature ( $r=$ $-0.58, P<0.0001)$. Thus, low rainfall and high average temperatures in August resulted in low yield, as was evident in the hot, dry summers of 2001, 2002, and 2003. Based on these factors, yield was generally more closely related to environmental conditions than to differences in crop rotations (Fig. 3C). Although some nominal trends were fairly consistent from year to year, statistically significant rotation effects on tuber yield were observed only within a few of the 8 years of study. $\mathrm{Ca}$ nola resulted in greater yield than other rotations in 1999, 2000, and 2004, with yields greater than green bean in all 3 years (16 to $26 \%$ greater), greater than potato and soybean in 1999 and 2000 (18 to $20 \%$ ), and greater than barley $(28 \%)$ in 1999. Barley also resulted in higher yields than green bean, canola, and rapeseed in 2003 (14\% higher than that of green bean) (Fig. 3C).

Occurrence of Verticillium wilt. Although not present during earlier years, in the 2005 field season, and then again in 2006, symptoms of early dying (wilt, chlorosis, defoliation, or premature senescence) became evident in potato plants throughout the field by early August. Assessment and sampling of the plants verified infection by $V$. dahliae, and plot-byplot disease assessments of wilt symptoms were made. By 1 September 2005, wilt incidence was moderate to high in all potato plots, ranging from 40 to $75 \%$ of plants showing symptoms. Although all plots were affected, significant differences in wilt among the rotation crops were observed, with barley, rapeseed, and sweet corn rotations resulting in lower wilt inci- dence (40 to $58 \%$ ) than the other rotations (68 to $75 \%$ ), and barley averaging lower wilt than all other rotations $(P=0.0001$; Fig. 4). Plating of potato stems sampled from the field indicated that the percentage of plant stems actually infected with $V$. dahliae was even higher, averaging 80 to $100 \%$ infection across all rotations (data not shown). In 2006, wilt incidence in the potato plots on 1 September was higher than in 2005, ranging from 64 to $98 \%$ among rotations. Significant differences among rotation crops were observed, with the barley rotation resulting in lower wilt incidence $(64 \%)$ than all other rotations, and canola, green bean, rapeseed, and sweet corn rotations showing less wilt (79 to $81 \%$ ) than soybean and potato rotations (95 to $98 \%$ wilt $)(P=0.0001$; Fig. 4$)$.

Cover crop effects on ground cover and soilborne diseases. Addition of a fall cover crop of winter rye to each of the existing rotations increased fall ground cover overall when ground cover was measured 4 weeks after the fall planting (Table 1). Both rotation and cover crop significantly affected fall ground cover $(P$ $<0.0001)$, and there also was a significant interaction between rotation and cover crop $(P<0.0001)$. The fall cover crop had the greatest effect on ground cover in rota-
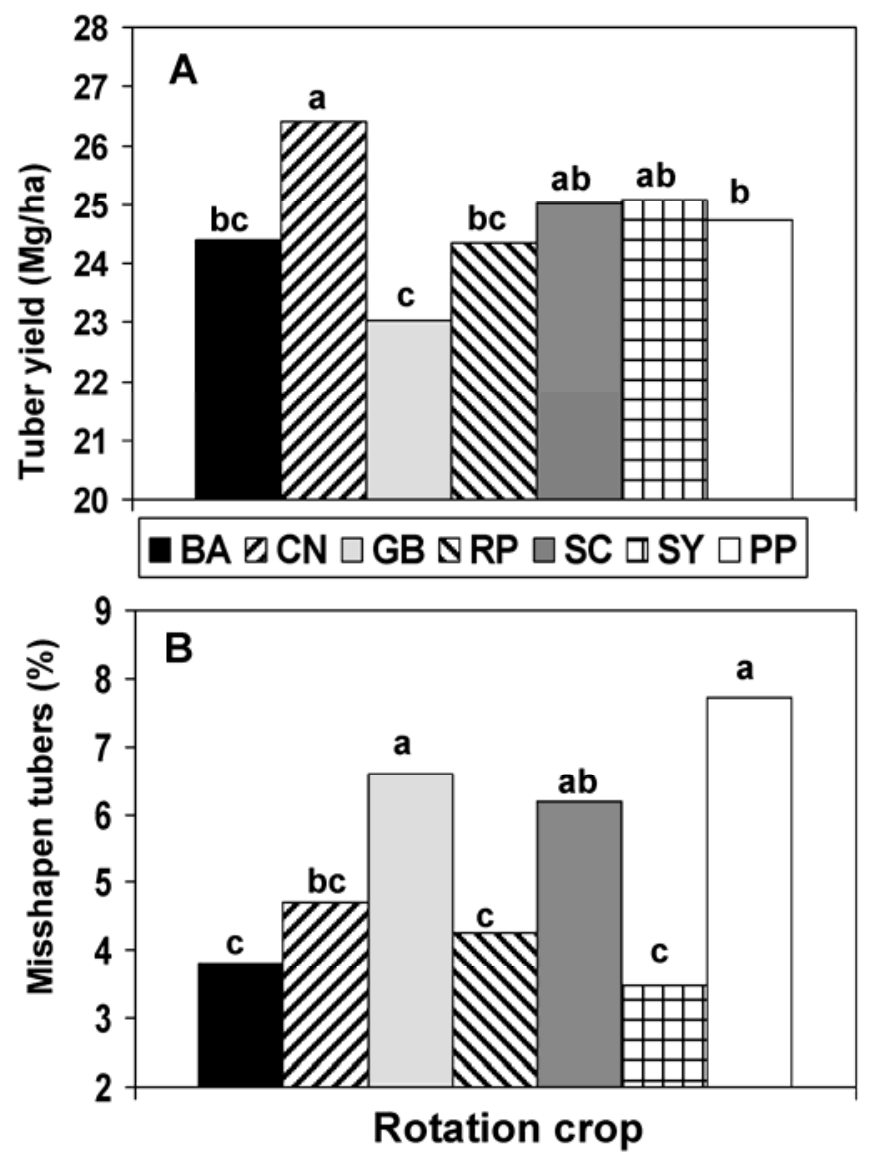

Fig. 2. Average effects of different rotation crops over an 8-year study period (1999 to 2006) on potato tuber production from 2-year crop rotations, as represented by $\mathbf{A}$, total tuber yield $(\mathrm{Mg} / \mathrm{ha})$ and $\mathbf{B}$, the percentage of severely misshaped tubers. $\mathrm{BA}=$ barley, $\mathrm{CN}=$ canola, $\mathrm{RP}=$ rapeseed, $\mathrm{GB}=$ green bean, $\mathrm{SC}=$ sweet corn, $\mathrm{SY}=$ soybean, and $\mathrm{PP}=$ potato (control). Bars topped by the same letter are not significantly different according to Fisher's protected least significant difference test $(P<0.05)$. 

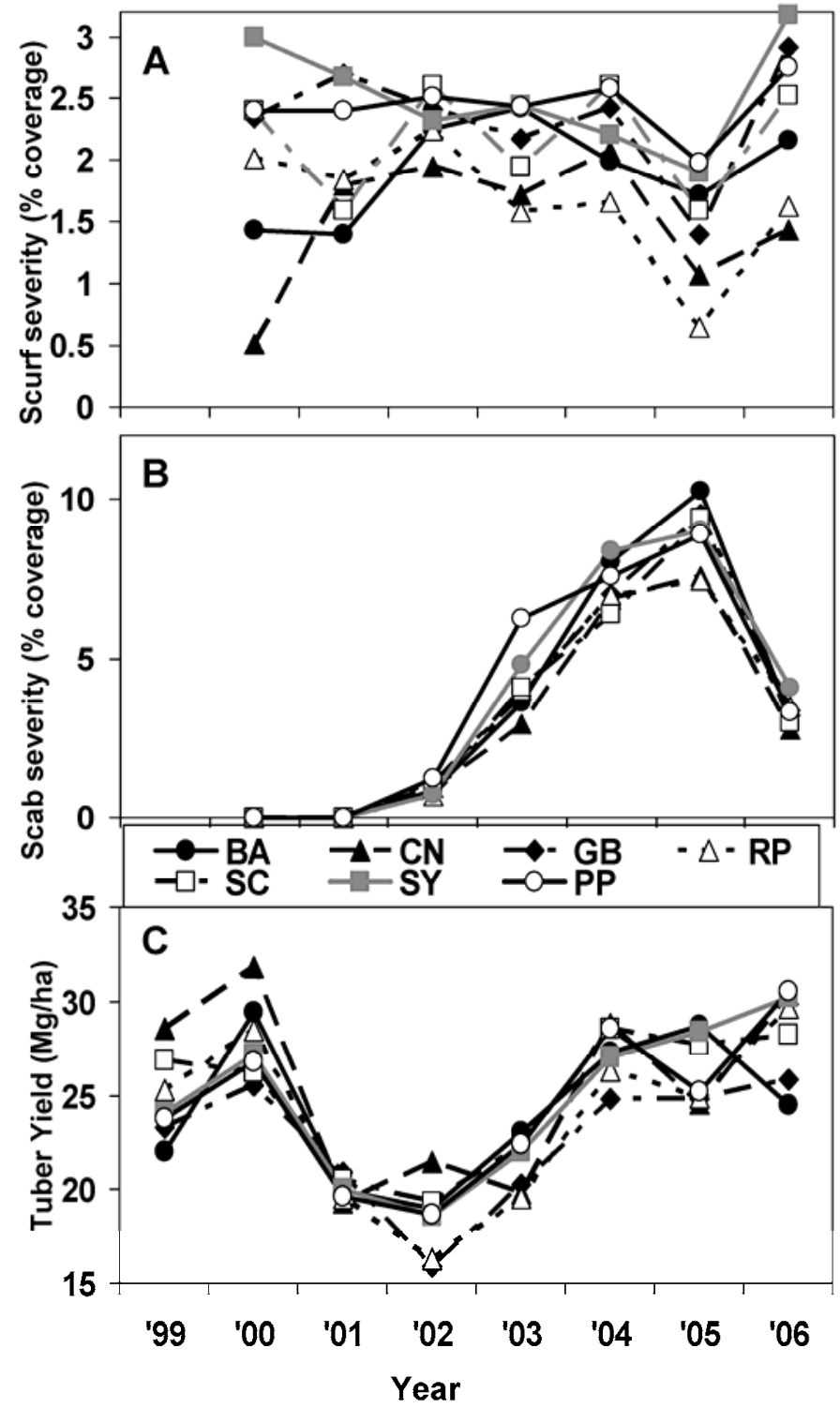

Fig. 3. Rotation crop effects on the development of potato tuber diseases and yield each year over an 8-year study period (1999 to 2006) from 2-year crop rotations for A, black scurf; B, common scab; and $\mathrm{C}$, total tuber yield. $\mathrm{BA}=$ barley, $\mathrm{CN}=$ canola, $\mathrm{RP}=$ rapeseed, $\mathrm{GB}=$ green bean, $\mathrm{SC}=$ sweet corn, $\mathrm{SY}$ = soybean, and $\mathrm{PP}=$ potato $($ control).

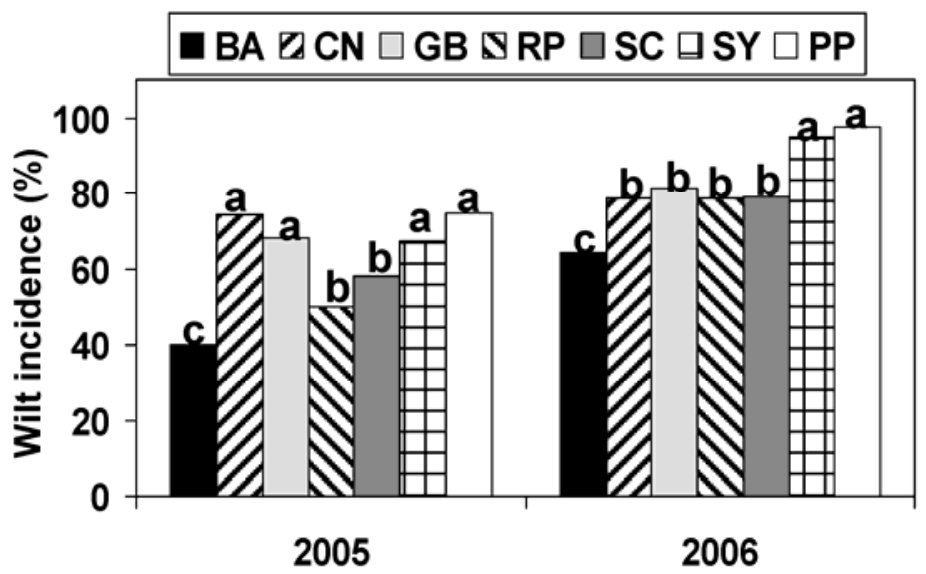

Fig. 4. Effects of different rotation crops on the development of Verticillium wilt symptoms (percent incidence) in potato plants evaluated in early September during the 2005 and 2006 field seasons. BA = barley, $\mathrm{CN}=$ canola, $\mathrm{RP}=$ rapeseed, $\mathrm{GB}=$ green bean, $\mathrm{SC}=$ sweet corn, $\mathrm{SY}=$ soybean, and $\mathrm{PP}=$ potato (control). Bars topped by the same letter are not significantly different according to Fisher's protected least significant difference test $(P<0.05)$. tions with low or sparse residual ground cover, such as potato, green bean, and sweet corn $(P=0.0001,0.0001$, and 0.003 , respectively for single degree-of-freedom contrasts), whereas the fall cover crop had almost no effect in rotations that already maintained high ground cover, such as canola and rapeseed. The barley rotation, which included an underseeded cover crop of either clover or ryegrass (and, thus, did not have a direct cover-no cover comparison) showed the highest fall ground cover regardless of whether the cover crop was clover (no cover factor) or ryegrass (cover). As expected, potato rotations showed almost no ground cover $(<4 \%)$, which was increased substantially with addition of the cover crop (to $13 \%$ ) but was still the lowest of all rotations (Table 1 ).

Addition of the fall cover crop resulted in significantly reduced black scurf severity (by $12.5 \%$ ) when averaged over all rotations ( $P=0.0001$ ), and significantly reduced scurf severity within each of the rotations (10 to $14 \%$ reduction, $P=0.0009$ to 0.020 ), with the exception of rapeseed $(P=0.912)$ (Table 1). Although scurf severity was not reduced by the addition of the cover crop within the rapeseed rotation, that rotation already had the lowest scurf level of any rotation. The biggest cover crop effect was observed in the barley rotation when the underseeded clover cover crop was replaced with ryegrass, and resulted in a reduction in scurf severity of $19 \%$. In addition, although scurf severity in the barley/clover rotation was comparable with that of potato or soybean rotations, the barley/ryegrass rotation resulted in scurf levels significantly lower than those of the soybean and potato rotations with cover crops (Table 1). Overall, the combination of a canola or rapeseed rotation in conjunction with a winter cover crop reduced scurf severity by 35 to $41 \%$ relative to the potato or soybean rotations without a cover crop or by 30 to $37 \%$ relative to the barley/clover rotation.

Severity of common scab was also significantly affected by addition of a winter rye cover crop, although to a lesser degree than severity of black scurf $(P=0.013)$. Common scab severity was high in all plots but the addition of the cover crop reduced overall scurf severity approximately $8 \%$, and significantly reduced scab severity in three of the rotations (canola, rapeseed, and potato) by 5 to $9 \%(P=$ $0.028,0.002$, and 0.003 , respectively; Table 1). As with scurf, the greatest decrease in common scab was achieved by replacing clover in the barley rotation with ryegrass, which reduced scab by $16 \%(P=$ $0.001)$ and resulted in significantly lower scab for the barley/ryegrass rotation compared with the sweet corn, soybean, and potato rotations with cover crop $(P=$ 0.001). Whether with or without a cover crop, canola and rapeseed rotations resulted in lower levels of black scurf and 
common scab than any other rotation (Table 1). The combined effect of using a canola or rapeseed rotation in conjunction with a winter rye cover crop reduced common scab severity by 29 to $30 \%$ relative to continuous potato or by 25 to $26 \%$ relative to a barley/clover rotation.

Cover crop effects on tuber yield. Over all rotations, addition of a cover crop resulted in a small but significant increase in total tuber yield of about $4 \%(P=0.008)$ (Table 1). Within individual rotations, addition of the cover crop significantly increased yield in the canola, rapeseed, sweet corn, and soybean rotations $(P=$ $0.038,0.0 .034,0.046$, and 0.036 , respectively), with increases of 5.3 to $9.0 \%$. No effect of cover crop on yield was observed in the green bean and potato rotations. With or without the cover crop, green bean rotations resulted in the lowest yields of all the rotations. Replacing the underseeded cover crop clover with ryegrass in the barley rotation resulted in a small (approximately $3.5 \%$ ) but not statistically significant increase in total yield $(P=0.093)$. Addition of the cover crop resulted in overall similar increases in marketable yield as observed with total yield $(P=$ 0.017 ), but cover crop did not significantly affect the percentage of misshapen tubers, either overall or within individual rotations ( $P=0.071$ to 0.816 , data not shown).

Rotation and cover crop effects on soil microbial communities. Various aspects of soil microbial communities, including populations of culturable bacteria and fungi, microbial activity, soil substrate utilization profiles, and soil FAME profiles, were significantly affected by both rotation and cover crop, as well as the interaction of rotation and cover crop throughout the study. Based on the average values from soil samples collected over three cropping seasons (sampled in the spring following the rotation crop and prior to planting potato), barley/clover rotations averaged higher general bacterial populations than all other rotations $(P=$ $0.0001)$. Rapeseed rotations resulted in the next highest populations, and soybean, sweet corn, and potato rotations averaged the lowest soil bacterial populations (Table 2). Culturable bacterial populations in continuous potato soils averaged roughly half of those present in the barley/clover rotation soils. Addition of the winter rye cover crop to the existing rotations resulted in overall increases in bacterial populations across all rotations, and significantly higher populations in five of the six rotations $(P=0.0001$ to 0.001$)$ (all but rapeseed, $P=0.269)$, resulting in increases of

Table 1. Effects of different rotation crops with and without an additional fall cover crop of winter rye on ground cover (measured in the fall), black scurf and common scab tuber diseases, and total tuber yield evaluated over three potato cropping years (3-year mean values) ${ }^{\mathrm{y}}$

\begin{tabular}{|c|c|c|c|c|c|c|c|c|}
\hline \multirow[b]{2}{*}{ Rotation crop } & \multicolumn{2}{|c|}{$\begin{array}{l}\text { Fall ground cover } \\
\text { (\% coverage })\end{array}$} & \multicolumn{2}{|c|}{$\begin{array}{c}\text { Black scurf } \\
(\% \text { tuber surface })^{z}\end{array}$} & \multicolumn{2}{|c|}{$\begin{array}{c}\text { Common scab } \\
(\% \text { tuber surface })^{z}\end{array}$} & \multicolumn{2}{|c|}{$\begin{array}{c}\text { Total yield } \\
\text { (Mg/ha) }\end{array}$} \\
\hline & Cover & No cover & Cover & No cover & Cover & No cover & Cover & No cover \\
\hline Barley & $99.0 \mathrm{a}$ & $98.4 \mathrm{a}$ & $1.66 b^{*}$ & $2.04 \mathrm{a}$ & $6.89 \mathrm{~d}^{*}$ & $8.18 \mathrm{a}$ & $27.14 \mathrm{a}$ & $26.21 \mathrm{a}$ \\
\hline Canola & $85.9 \mathrm{~b}$ & $87.5 \mathrm{~b}$ & $1.43 c^{*}$ & $1.65 \mathrm{~b}$ & $6.04 \mathrm{e}^{*}$ & $6.39 c$ & $25.10 \mathrm{bc}$ & $23.78 \mathrm{bc} *$ \\
\hline Green Bean & $64.9 \mathrm{~d}$ & $43.0 \mathrm{~d}^{*}$ & $1.79 a b^{*}$ & $2.00 \mathrm{a}$ & $7.25 \mathrm{~cd}$ & $7.50 \mathrm{~b}$ & $23.88 \mathrm{c}$ & $23.32 \mathrm{c}$ \\
\hline Rapeseed & $75.8 \mathrm{c}$ & $80.5 \mathrm{~b}$ & $1.29 \mathrm{c}$ & $1.30 \mathrm{c}$ & $6.10 \mathrm{e}^{*}$ & $6.50 \mathrm{c}$ & $25.68 \mathrm{ab}$ & $23.57 \mathrm{bc}^{*}$ \\
\hline Sweet corn & $79.8 \mathrm{bc}$ & $67.5 c^{*}$ & $1.80 \mathrm{ab}^{*}$ & $2.05 \mathrm{a}$ & $7.50 \mathrm{bc}$ & $7.35 \mathrm{~b}$ & $27.37 \mathrm{a}$ & $25.60 \mathrm{ab}^{*}$ \\
\hline Soybean & $44.9 \mathrm{e}$ & $43.1 \mathrm{~d}$ & $1.90 \mathrm{a}^{*}$ & $2.19 \mathrm{a}$ & $8.32 \mathrm{a}$ & $8.52 \mathrm{a}$ & $26.83 \mathrm{ab}$ & $25.48 \mathrm{ab}^{*}$ \\
\hline Potato & $13.0 \mathrm{f}$ & $3.7 \mathrm{e}^{*}$ & $1.89 \mathrm{a}^{*}$ & $2.19 \mathrm{a}$ & $7.92 \mathrm{ab}^{*}$ & $8.60 \mathrm{a}$ & $24.77 \mathrm{c}$ & $25.60 \mathrm{ab}$ \\
\hline $\operatorname{LSD}(P=0.05)$ & 7.1 & 7.2 & 0.16 & 0.18 & 0.42 & 0.44 & 1.68 & 2.15 \\
\hline Mean & 66.2 & $60.5 *$ & $1.68 *$ & 1.92 & $7.67 *$ & 8.30 & 25.83 & $24.94 *$ \\
\hline
\end{tabular}

y Cover refers to the presence of a fall cover crop of winter rye following each rotation crop and No Cover refers to the absence of any cover crop (fall fallow). However, for the barley rotation only, because that original rotation included an underseeded cover crop of clover, a different underseeded cover crop (ryegrass) was used for the Cover treatment. Thus, for barley only, Cover refers to the ryegrass cover crop and No Cover refers to the original clover cover crop. Means within each column followed by the same letter are not significantly different according to Fisher's protected least significant difference (LSD) test at $P=0.05$. Means followed by an asterisk are significantly less than the corresponding mean in the cover crop or no cover crop comparison for that rotation crop and factor combination, based on single degree of freedom contrast at $P=0.05$.

${ }^{\mathrm{z}}$ Severity of black scurf and common scab were estimated based on the average percentage of tuber surface covered with lesions. In total, 120 tubers were assessed per treatment ( 4 replications $\times 30$ tubers/replication) per year.

Table 2. Effects of different rotation crops with and without an additional fall cover crop of winter rye on soil microbial characteristics, including bacterial populations, fungal populations, and microbial activity evaluated over three potato cropping years $\left(3\right.$-year mean values) ${ }^{\mathrm{x}}$

\begin{tabular}{|c|c|c|c|c|c|c|}
\hline \multirow[b]{2}{*}{ Rotation crop } & \multicolumn{2}{|c|}{$\begin{array}{l}\text { Bacterial populations } \\
\left(\times 10^{7} \mathrm{CFU} / \mathrm{g} \text { of soil }\right)^{\mathrm{y}}\end{array}$} & \multicolumn{2}{|c|}{$\begin{array}{l}\text { Fungal populations } \\
\left(\times 10^{5} \mathrm{CFU} / \mathrm{g} \text { of soil }\right)^{\mathrm{y}}\end{array}$} & \multicolumn{2}{|c|}{$\begin{array}{c}\text { Microbial activity } \\
(\text { AWCD) (optical density })^{\mathrm{z}}\end{array}$} \\
\hline & Cover & No cover & Cover & No cover & Cover & No cover \\
\hline Barley & $8.98 b^{*}$ & $11.08 \mathrm{a}$ & $6.01 \mathrm{a}$ & $5.69 \mathrm{a}$ & $0.510 \mathrm{bc}^{*}$ & $0.544 \mathrm{a}$ \\
\hline Canola & $8.68 \mathrm{bc}$ & $7.45 \mathrm{c}^{*}$ & $4.19 c^{*}$ & $5.12 \mathrm{ab}$ & $0.531 \mathrm{ab}$ & $0.489 \mathrm{~b}$ \\
\hline Green Bean & $8.90 \mathrm{bc}$ & $6.69 \mathrm{~cd}^{*}$ & $4.40 \mathrm{c}$ & $4.26 \mathrm{~cd}$ & $0.536 \mathrm{ab}$ & $0.425 \mathrm{~cd}^{*}$ \\
\hline Rapeseed & $10.42 \mathrm{a}$ & $9.83 \mathrm{~b}$ & $4.22 \mathrm{c}^{*}$ & $4.93 \mathrm{bc}$ & $0.572 \mathrm{a}$ & $0.546 \mathrm{a}$ \\
\hline Sweet corn & $8.73 \mathrm{bc}$ & $6.22 \mathrm{~d}^{*}$ & $4.22 \mathrm{c}^{*}$ & $4.79 \mathrm{bc}$ & $0.490 \mathrm{~cd}$ & $0.447 \mathrm{bc}^{*}$ \\
\hline Soybean & $7.45 \mathrm{~d}$ & $6.35 \mathrm{~d}^{*}$ & $3.84 \mathrm{c}$ & $4.02 \mathrm{~d}$ & $0.462 \mathrm{~d}$ & $0.472 \mathrm{bc}$ \\
\hline Potato & $7.91 \mathrm{~cd}$ & $5.72 \mathrm{~d}^{*}$ & $5.20 \mathrm{~b}$ & $5.50 \mathrm{ab}$ & $0.544 \mathrm{ab}$ & $0.387 \mathrm{~d}^{*}$ \\
\hline $\operatorname{LSD}(P=0.05)$ & 0.80 & 1.04 & 0.58 & 0.69 & 0.046 & 0.049 \\
\hline Mean & 8.73 & $7.62 *$ & $4.58 *$ & 4.90 & 0.521 & $0.473 *$ \\
\hline
\end{tabular}

${ }^{x}$ Cover refers to the presence of a fall cover crop of winter rye following each rotation crop and No Cover refers to the absence of any cover crop (fall fallow). However, for the barley rotation only, because that original rotation included an underseeded cover crop of clover, a different underseeded cover crop (ryegrass) was used for the Cover treatment. Thus, for barley only, Cover refers to the ryegrass cover crop and No Cover refers to the original clover cover crop. Means within each column followed by the same letter are not significantly different according to Fisher's protected least significant difference (LSD) test at $P=0.05$. Means followed by an asterisk are significantly less than the corresponding mean in the cover crop or no cover crop comparison for that rotation crop and factor combination based on single degree of freedom contrast at $P=0.05$.

y Total culturable soil bacterial and fungal populations were determined by serial dilution plating on 0.1-strength tryptic soy agar and potato dextrose agar with antibiotics, respectively. Composite soil samples were collected from each plot in the spring of each year following the rotation crop and prior to planting the potato crop. Three subsamples were independently plated for each composite soil sample.

${ }^{\mathrm{z}}$ Relative general microbial activity was estimated by the average well color development (AWCD; measured by optical density) representing average substrate utilization across all 95 carbon substrates in Biolog GN2 plates. Two subsamples and plates were prepared for each composite soil sample. 
17 to $40 \%$. Replacing clover with ryegrass as the underseeded cover crop with barley, however, resulted in an average reduction in bacterial populations $(P=$ 0.0003; Table 2).

With no cover crop, barley/clover and potato rotations averaged the highest culturable fungal populations. Soybean and green bean rotations averaged the lowest $(P=0.001$; Table 2). Addition of the winter rye fall cover crop to the rotations resulted in an overall reduction in soil fungal populations $(P=0.003)$, and significant reductions were associated with canola, rapeseed, and sweet corn rotations $(P=$
0.0006, 0.026, and 0.047, respectively). Replacing the clover cover crop with ryegrass in the barley rotation had no significant effect on fungal populations, although a slight increase was observed $(P=0.276)$. With the cover crop added, barley/ryegrass and continuous potato averaged higher fungal populations than all other rotations $(P=0.0001$; Table 2).

General microbial activity, as estimated by average substrate utilization across numerous carbon sources, tended to be highest in soils from the barley/clover and rapeseed rotations and generally lowest in the potato rotations $(P=0.0001$; Table 2$)$.

Table 3. Effects of different rotation crops with and without an additional fall cover crop of winter rye on soil substrate utilization characteristics, including substrate richness and substrate diversity evaluated over four potato cropping years (4-year mean values) ${ }^{\mathrm{x}}$

\begin{tabular}{lccccc}
\hline & \multicolumn{2}{c}{$\begin{array}{c}\text { Substrate richness } \\
\text { (average no. of substrates utilized) }\end{array}$} & & & \multicolumn{2}{c}{$\begin{array}{c}\text { Substrate diversity } \\
\text { (Shannon diversity index) }\end{array}$} \\
\cline { 2 - 3 } \cline { 5 - 6 } Rotation crop & Cover & No cover & & Cover & No cover \\
\hline Barley & $59.4 \mathrm{a}$ & $57.3 \mathrm{a}$ & & $4.14 \mathrm{ab}$ & $4.13 \mathrm{a}$ \\
Canola & $58.1 \mathrm{ab}$ & $54.6 \mathrm{bc}^{*}$ & & $4.18 \mathrm{a}$ & $4.08 \mathrm{~b}^{*}$ \\
Green Bean & $57.6 \mathrm{bc}$ & $53.3 \mathrm{bc}^{*}$ & & $4.11 \mathrm{bc}$ & $4.06 \mathrm{bc}^{*}$ \\
Rapeseed & $57.4 \mathrm{bc}$ & $54.9 \mathrm{~b}$ & & $4.08 \mathrm{bc}$ & $4.08 \mathrm{~b}$ \\
Sweet corn & $59.3 \mathrm{a}$ & $53.2 \mathrm{bc}^{*}$ & & $4.16 \mathrm{a}$ & $4.06 \mathrm{bc}^{*}$ \\
Soybean & $56.1 \mathrm{c}$ & $53.1 \mathrm{c}^{*}$ & & $4.06 \mathrm{c}$ & $4.04 \mathrm{c}$ \\
Potato & $53.1 \mathrm{~d}$ & $50.4 \mathrm{~d}^{*}$ & & $3.99 \mathrm{~d}$ & $3.98 \mathrm{~d}$ \\
Mean & 57.3 & $53.8^{*}$ & & 4.10 & $4.06^{*}$ \\
\hline
\end{tabular}

${ }^{x}$ Cover refers to the presence of a fall cover crop of winter rye following each rotation crop and No Cover refers to the absence of any cover crop (fall fallow). However, for the barley rotation only, because that original rotation included an underseeded cover crop of clover, a different underseeded cover crop (ryegrass) was used for the Cover treatment. Thus, for barley only, Cover refers to the ryegrass cover crop and No Cover refers to the original clover cover crop. Means within each column followed by the same letter are not significantly different according to Fisher's protected least significant difference test at $P=0.05$. Means followed by an asterisk are significantly less than the corresponding mean in the cover crop/no cover crop comparison for that rotation crop and factor combination based on single degree of freedom contrast at $P=0.05$.

${ }^{y}$ Substrate richness refers to the average number of substrates utilized (optical density $>0.25$ ) out of 95 total.

${ }^{2}$ Substrate diversity refers to the Shannon diversity index calculated over all substrates from Biolog GN2 plates (72-h incubation).

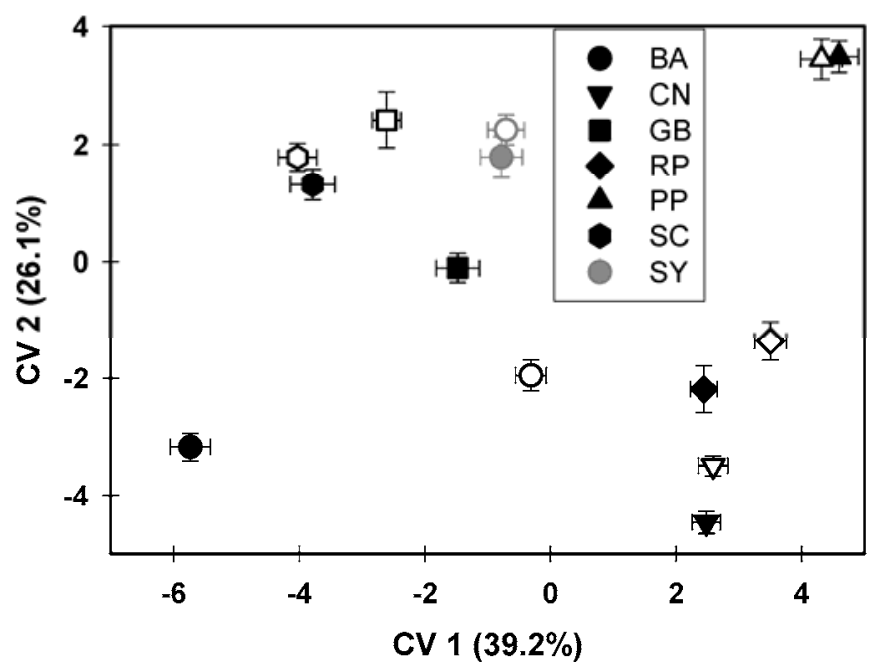

Fig. 5. Effects of seven different 2-year rotations with (CC, filled symbols) and without (NC, open symbols) a fall cover crop of winter rye on soil microbial community characteristics, as represented by soil fatty acid methyl ester (FAME) profile analysis (canonical variates [CV] 1 and 2 from canonical variates analysis of 45 FAMEs) measured in spring 2006, following the rotation crop and prior to planting potato (single-year representative of differences observed in multiple years). Error bars represent the standard error of the mean. Numbers in parentheses refer to the percentage of canonical variability accounted for by each CV.

Addition of the winter rye cover crop resulted in a general increase in microbial activity when averaged over all rotations $(P=0.0001)$, and significantly increased with the canola, green bean, sweet corn, and potato rotations $(P=0.052,0.0001$, 0.0003 , and 0.016 , respectively; Table 2). Replacing the clover cover crop with ryegrass in the barley rotation resulted in a small reduction in microbial activity $(P=$ 0.046). With the cover crop added, rapeseed rotations averaged the highest levels of microbial activity $(P=0.0001)$.

Measures of substrate richness and substrate diversity from Biolog plates, as indicators of microbial functional richness and diversity, also were significantly affected by rotation and cover crop. Overall, barley rotations averaged the highest substrate richness and soybean and potato the lowest $(P=0.0001$; Table 3). Substrate richness was also higher with the addition of a cover crop than without when averaged over all rotations, with significant increases observed within all rotations except barley and rapeseed. For substrate diversity, barley, canola, and sweet corn rotations averaged the highest diversity, whereas soybean and potato averaged the lowest $(P=0.0001)$. Addition of the fall cover crop increased substrate diversity averaged over all rotations, with significant increases observed within the canola, sweet corn, rapeseed, and green bean rotations (Table 3).

Analysis of the soil fatty acid data indicated that soil FAME profiles were distinctly different among the different crop rotations $(P=0.0001)$, and that addition of a cover crop to the rotations also resulted in detectable changes in soil microbial community characteristics. Graphical depiction of the first two canonical variates (CV1 and CV2) from canonical variates analysis indicated that, in general, each crop rotation produced microbial characteristics distinct from each other rotation (Fig. 5). For most rotations, the effect of the rotation crop was much stronger than that of the cover crop, evident by the greater separation of different rotation crops and closer proximity of the cover and no-cover values within a particular rotation (for sweet corn, soybean, canola, and rapeseed, in particular). However, the barley/clover rotation showed a much different profile than the corresponding barley/ryegrass rotation, indicating that this replacement results in dramatic changes in microbial community characteristics. Green bean rotations also showed a larger cover crop shift than most other rotations.

Looking further at FAME profiles among the rotations, fatty acid classes and individual FAMES representing different groups of microorganisms also differed significantly among rotations. Saturated straight-chain fatty acids, which are present in all organisms and not indicative of any particular group of organisms, ac- 
counted for the largest FAME group for potato and soybean rotations but were substantially lower for barley, canola, and rapeseed rotations, whereas monounsaturated fatty acids, which are associated with gram-negative bacteria and mycorrhizae, tended to be highest in sweet corn and barley rotations and lowest in continuous potato (Table 4). Polyunsaturated fatty acids, which are FAME indicators for fungi, tended to be highest in the rapeseed, barley, and canola rotations and lowest in the soybean and potato rotations. The ratio of monounsaturated to saturated fatty acids, which can be used as an indicator of soil environmental conditions, was highest for barley rotations and lowest for potato. Addition of a cover crop resulted in an overall increase in the percentage of monounsaturated fatty acids and in the ratio of monounsaturated to saturated fatty acids (Table 4). The percent abundance of the individual FAME $16: 1 \omega 5 \mathrm{c}$, which is an indicator for arbuscular mycorrhizal fungi, was significantly higher within the sweet corn rotation than all other rotations, and was lowest in the rapeseed, canola, and potato rotations (Table 5). The individual FAME that serves as an indicator for fungi, 18:2 $\omega 6 \mathrm{c}$, tended to be highest in the rapeseed, barley, and canola rotations, and lowest in continuous potato. Another FAME marker, 18:1 $\omega 9 \mathrm{c}$, which is present primarily in gram-negative bacteria as well some fungi, tended to be lower in the soybean and potato rotations than in the other rotations. Addition of the winter rye cover crop resulted in overall increases in the percentages of $16: 1 \omega 5 \mathrm{c}$ and $18: 1 \omega 9 \mathrm{c}$ but not 18:2 $\omega 6 \mathrm{c}$, relative to no cover crop.

\section{DISCUSSION}

In this research, long-term effects of different crop rotations were evaluated, and potato disease, yield, and soil microbial community data were collected over a 7- to 8-year period, representing several (four to five) 2-year rotation cycles. Canola and rapeseed were the most consistent and effective rotation crops for reducing the soilborne diseases commonly observed in these fields, including Rhizoctonia canker, black scurf, and common scab, with overall reductions (averaged over all seasons) ranging from 18 to $38 \%$. Green bean and soybean rotations had no positive benefits related to any of the soilborne diseases, with disease development comparable with continuous potato (that is, no rotation at all). Barley/clover, on the other hand, demonstrated reductions in Rhizoctonia canker and black scurf through the first couple of rotation cycles, after which these diseases increased to levels comparable with continuous potato.

Some previous research had suggested that the rotation crop used in 2-year rotations was not that important as long as it was not a host to the pathogen in question, and observed that a wide variety of non- host crops provided comparable reductions in Rhizoctonia canker relative to continuous potato $(27,29,60)$. However, these were short-term trials, and differences among rotation crops may have become more evident over time. Disease reduction also was assumed to be primarily the result of a break in the host-pathogen cycle or directly related to the amount of time between host crops rather than to specific properties of the rotation crop. It is important to consider that, generally, crop rotations can reduce soilborne pathogens by any (or all) of three general mechanisms: (i) by serving to interrupt or break the host-pathogen cycle of inoculum production, growth, or survival; (ii) by altering the soil physical, chemical, or biological characteristics, making the soil environment less conducive for pathogen development or survival, often stimulating mi- crobial activity, diversity, or plantbeneficial microbes; and (iii) by direct inhibition of pathogens, either through production of inhibitory or toxic compounds in the roots or plant residues or by stimulating specific microbial antagonists which directly suppress pathogen inoculum (37). There is a serious limitation to the first mechanism, in that most soilborne pathogens can survive many years in the absence of a host. Although it is often assumed that crop rotations act primarily through the first mechanism, this may not always be the case. Consequently, it is often stated that crop rotations are not very effective in controlling pathogens with wide host ranges or long survival periods $(15,61)$. For crop rotations to be more effective in disease management, the second and third mechanisms (which involve the active suppression, reduction, or de-

Table 4. Effects of different rotation crops and presence (CC) or absence (NC) of a fall cover crop of winter rye on selected soil microbial fatty acid methyl ester (FAME) characteristics, including the percent abundance of FAME classes of saturated straight-chain, monounsaturated, and polyunsaturated fatty acids, as well as the ratio of monounsaturated to saturated fatty acids measured in the spring of each year and averaged over four potato cropping years (4-year mean values) ${ }^{\mathrm{y}}$

\begin{tabular}{lcccc}
\hline Rotation crop & $\begin{array}{c}\text { Saturated } \\
(\boldsymbol{\%})\end{array}$ & $\begin{array}{c}\text { Monounsaturated } \\
(\boldsymbol{\%})\end{array}$ & $\begin{array}{c}\text { Polyunsaturated } \\
(\boldsymbol{\%})\end{array}$ & $\begin{array}{c}\text { Mono:saturated } \\
(\text { ratio })\end{array}$ \\
\hline Barley/clover & $24.34 \mathrm{c}$ & $26.18 \mathrm{a}$ & $8.71 \mathrm{ab}$ & $1.12 \mathrm{a}$ \\
Canola & $25.65 \mathrm{~b}$ & $23.79 \mathrm{c}$ & $8.51 \mathrm{~b}$ & $0.95 \mathrm{c}$ \\
Green Bean & $26.39 \mathrm{ab}$ & $25.11 \mathrm{~b}$ & $7.71 \mathrm{c}$ & $0.98 \mathrm{bc}$ \\
Rapeseed & $25.61 \mathrm{~b}$ & $23.90 \mathrm{~b}$ & $9.33 \mathrm{a}$ & $0.96 \mathrm{c}$ \\
Sweet corn & $26.55 \mathrm{ab}$ & $26.41 \mathrm{a}$ & $7.02 \mathrm{~cd}$ & $1.03 \mathrm{~b}$ \\
Soybean & $26.78 \mathrm{a}$ & $25.66 \mathrm{ab}$ & $6.73 \mathrm{~d}$ & $0.99 \mathrm{bc}$ \\
Potato & $26.67 \mathrm{a}$ & $22.26 \mathrm{~d}$ & $6.89 \mathrm{~d}$ & $0.85 \mathrm{~d}$ \\
LSD $(P=0.05)$ & 0.88 & 0.79 & 0.73 & 0.05 \\
Cover crop & & & & $1.007 \mathrm{~A}$ \\
CC & $25.8 \mathrm{~A}$ & $25.2 \mathrm{~A}$ & $7.84 \mathrm{~A}$ & $0.95 \mathrm{~B}$ \\
NC & $26.2 \mathrm{~A}$ & $24.3 \mathrm{~B}$ & $7.81 \mathrm{~A}$ & \\
\hline
\end{tabular}

${ }^{y}$ Means within each column followed by the same letter are not significantly different according to Fisher's protected least significant difference (LSD) test at $P=0.05$.

${ }^{\mathrm{z}}$ Cover crop refers to either the presence (CC) or absence (NC) of a fall cover crop of winter rye following each rotation crop. Because there was no significant interaction between the main factors (rotation and cover crop), means for each factor are presented.

Table 5. Effects of different rotation crops with and without an additional fall cover crop of winter rye on the relative abundance (percentage of total) of the indicator fatty acid methyl esters (FAMEs) 16:1 $\omega 6 \mathrm{c}, 18: 2 \omega 6 \mathrm{c}$, and 18:1 $\omega 9 \mathrm{c}$ evaluated over three potato cropping years (spring sampling, 3-year mean values)

\begin{tabular}{lccc}
\hline & \multicolumn{3}{c}{ Indicator FAMEs $^{\mathbf{y}}$} \\
\cline { 2 - 4 } Rotation crop & $\mathbf{1 6 : 1} \mathbf{\omega 5 \mathbf { c }}$ & $\mathbf{1 8 : 2} \mathbf{\omega 6} \mathbf{c}$ & $\mathbf{1 8 : 1} \mathbf{\omega 9 c}$ \\
\hline Barley/clover & $4.23 \mathrm{~b}$ & $4.08 \mathrm{~b}$ & $3.83 \mathrm{a}$ \\
Canola & $1.33 \mathrm{e}$ & $4.06 \mathrm{~b}$ & $3.86 \mathrm{a}$ \\
Green Bean & $3.67 \mathrm{c}$ & $3.57 \mathrm{bc}$ & $3.42 \mathrm{a}$ \\
Rapeseed & $1.79 \mathrm{~d}$ & $4.73 \mathrm{a}$ & $3.59 \mathrm{a}$ \\
Sweet corn & $5.08 \mathrm{a}$ & $3.68 \mathrm{bc}$ & $3.65 \mathrm{a}$ \\
Soybean & $4.37 \mathrm{~b}$ & $3.47 \mathrm{c}$ & $2.91 \mathrm{~b}$ \\
Potato & $1.35 \mathrm{e}$ & $2.83 \mathrm{~d}$ & $2.44 \mathrm{c}$ \\
Cover crop & & & \\
CC & $3.30 \mathrm{~A}$ & $3.80 \mathrm{~A}$ & $3.50 \mathrm{~A}$ \\
NC & $2.97 \mathrm{~B}$ & $3.75 \mathrm{~A}$ & $3.27 \mathrm{~B}$ \\
\hline
\end{tabular}

${ }^{y}$ FAMEs that are specifically associated with particular organisms or groups are considered indicators of the relative abundance of those groups, including 16:1 $\omega 5 \mathrm{c}$ for mycorrhizae, 18:2 $\omega 6 \mathrm{c}$ for fungi, and 18:1 $\omega 9 \mathrm{c}$ for gram-negative bacteria and certain fungi. Means within each column followed by the same letter for each variable group are not significantly different according to Fisher's protected least significant difference test at $P=0.05$.

${ }^{\mathrm{z}}$ Cover crop refers to either the presence (CC) or absence (NC) of a fall cover crop of winter rye following each rotation crop. Because there was no significant interaction between the main factors (rotation and cover crop), means for each factor are presented. 
struction of pathogen propagules, survival, or disease-causing activity) must be more fully explored and exploited.

Crops and rotations that take such an active role in reducing diseases can be referred to as disease suppressive. Grass and forage crops with extensive root systems grown as rotation or cover crops are known to increase microbial populations, activity, and diversity, and may also suppress diseases $(1,18,20,33)$. Brassica crops, such as canola and rapeseed, actively affect pathogen populations and microbial communities. There has been much recent research and interest in the potential of Brassica crops for pest and disease management $(36,45,48)$. In other research, incorporation of Brassica residues had greater impact on soil microbial communities than other organic amendments or Brassica residues that were not incorporated, and also more effectively reduced soilborne disease (17). In recent studies in potato systems, incorporation of either rye or mustard residues increased root health but mustard was superior to rye (58), and a rapeseed cover crop efficiently suppressed weeds compared with other cover crops and also increased yield relative to fallow and ryegrass (9). Our research supports the high potential for using Brassica crops as rotation, cover, or green manure crops for the suppression of soilborne diseases (34,3638). For the most part, biofumigation through production of toxic metabolites is the presumed mechanism but additional recent research has indicated that effects mediated through soil microbial communities also play an important role $(12,36,47)$ In addition, almost all of the previous biofumigation research with Brassica spp. has dealt with green manure crops. In the present research, canola was grown as a harvested cash crop and biomass was not incorporated into the soil. Thus, in this research, beneficial effects due to canola were not related to the biofumigation effects of incorporated green biomass but were simply a result of growing the plants in the soil. In previous research, canola and rapeseed green manures provided greater reductions in Rhizoctonia diseases than mustard crops with much higher glucosinolate levels, indicating that biofumigation products were not the primary mechanism of action (36). Regardless of the mechanisms, or because of a combination of these mechanisms, Brassica crops appear to provide some management of multiple soilborne diseases.

In these studies, modest but significant benefits were attributed to the addition of the winter rye cover crop across all rotations. Although effects varied somewhat depending on the rotation used, overall, addition of the cover crop increased fall ground cover, reduced severity of black scurf and common scab tuber diseases by 12 and $8 \%$, and increased tuber yield by $4 \%$, when averaged over all rotations for three potato cropping seasons. Changing the cover crop underseeded with barley from red clover to ryegrass also resulted in significant reductions in black scurf and common scab (approximately 19\%), supporting previous studies indicating that red clover can contribute to black scurf and common scab problems on potato crops $(5,37)$. Thus, ryegrass may be a preferable cover crop for underseeding with barley in potato rotations.

Red clover, whether as a rotation or cover crop, has produced varying results in different studies. In a long-term (11-year) comparison among 2-year rotations on Prince Edward Island, Canada, a red clover rotation reduced soilborne diseases, including black scurf, common scab, and silver scurf, compared with ryegrass and barley but also resulted in higher populations of specific plant-parasitic nematodes, resulting in lower yields (10). In some short-term trials in Maine, a red clover cover crop also was associated with lower soilborne diseases (24). Red clover has also been associated with the stimulation of bacterial endophytes that are antagonistic to diseases and may enhance disease suppression (63). However, in other shortand long-term rotation trials in Maine, red clover was associated with increased levels of $R$. solani and increased stem canker and black scurf $(5,37)$. In these and other tests, it was observed that red clover may act as a host of $R$. solani under certain conditions, resulting in substantial increases in inoculum and disease relative to other rotations.

Verticillium wilt, although not detected in the fields through the first several years of these studies, developed to become a prominent problem in all plots in later years, with incidence of wilt ranging from 40 to $100 \%$ in 2005 and 2006. Although the barley rotation resulted in the lowest levels of wilt among the different rotations, wilt symptoms were severe in all plots and rotations. However, most of these effects were not evident until the fourth or fifth rotation cycle. Common scab also was observed to increase steadily in all rotations through the later years of the study. Thus, although some rotation crops significantly reduced soilborne disease relative to other 2-year rotations, none of the 2-year rotations were effective in preventing long-term increases in diseases such as Verticillium wilt and common scab. The development of disease problems only after several rotation cycles also is an indication of the importance of longer-term studies such as this. Disease assessments only based on short-term studies would have missed the development of these diseases, and could result in erroneous recommendations of potentially undesirable management practices. Such disease problems demonstrate the limitations of 2year rotations; even with the best available rotation crop, 2 years between potato crops may not be sufficient to prevent build-up of some soilborne diseases. However, this research can also be helpful in determining which crops may be best to use within 3or 4-year rotations to provide the best combination of attributes. Previous research with 3-year rotations and these same rotation crops also indicated the benefits of barley, canola, and sweet corn within the 3-year rotations (37).

Our research indicates that each rotation crop can impart somewhat unique microbial characteristics, or at least influence the structure and function of those microbial communities $(34,35,37)$. Thus, it is possible that those crops that can support the most beneficial assemblage of rhizobacteria and soil microorganisms for potato health and productivity may have the best chance to provide effective disease suppression and, potentially, more sustainable crop production. In this study, and consistent with those previous studies, barley and Brassica rotations consistently had higher bacterial populations and microbial activity, as well as generally higher substrate richness and diversity, than most other rotations, whereas continuous potato (no rotation) resulted in the lowest levels for those microbial parameters. This finding supports the concept that, in general, higher microbial activity and diversity may help suppress crop diseases $(18,20,67)$. However, increased microbial activity alone is generally not sufficient, because many systems with high organic matter and high activity are not disease suppressive. For example, organic amendments, per se, were not consistently linked with disease suppression in a survey of hundreds of research studies; however, disease suppression was more closely related to microbiological parameters (such as microbial biomass, populations, and activity) than chemical parameters (such as chemical composition, $\mathrm{C}: \mathrm{N}$ ratio, $\mathrm{pH}$, and so on; 3). In our study, soil bacterial populations and microbial activity were significantly higher in the barley/clover rotation than the barley/ryegrass (with cover crop) rotation, yet barley/ryegrass resulted in significantly lower black scurf and common scab disease levels. In this case, the somewhat higher microbial populations for barley/clover were somewhat negated by the fact that clover can act as a host for $R$. solani and result in increased pathogen populations and disease problems $(5,37)$.

FAME profiles revealed distinct differences in soil microbial community characteristics associated with each rotation. Differences in FAME profiles were related to differences within both the bacterial and fungal communities. The differences generally associated with bacterial communities were primarily delineated along CV1 and those of fungi along CV2. Both of the Brassica crops, rapeseed and canola, resulted in very similar effects on microbial communities (same types of community 
shifts) but these effects were very different from all other rotations. FAME 16:1 $\omega 5 \mathrm{c}$ was important for differentiating among cropping systems, with sweet corn and barley/ryegrass rotations showing high levels, indicating higher mycorrhizae populations, whereas potato and the Brassica rotations had low levels. Thus, although mycorrhizae may have been associated with disease reduction in barley rotations, they were not related to disease reduction within Brassica rotations. Microbial community differences between continuous potato and Brassica rotations were more closely related to differences in fungal characteristics. Thus, the specific ways that these Brassica crops effect microbial communities appear to be quite distinct from most other crops or other additions of organic matter (17). In potato research in Italy, fungal diversity was greater and species composition differed in longer rotations than in continuous or short-term rotations, and nonrotations resulted in increased pathogen densities (44). Although the indication of low fungal populations for continuous potato by the FAME data appears to contradict the dilution plate population results, there is a well-known explanation for this, as discussed in our previous research $(34,37)$. Plate counts can be dominated by spores and conidia, and we have previously shown that a particular Penicillium sp. that is associated with potato roots (populations increased with potato cultivation) produces abundant conidia and largely accounts for the increased populations observed with plate counts in potato rotations. FAME data should more accurately reflect actual fungal populations active in the soil than plate counts $(34,37)$.

The ratio of monounsaturated to saturated fatty acids has been used as an indicator of soil environmental conditions (69), with values greater than 1 indicating relatively high $\mathrm{C}$ content and organic inputs, values right around 1 for most cultivated soils, and values less than 1 indicating soils characterized by low substrate and organic inputs. Results from the present study are consistent with our previous research findings, showing that continuous potato cropping had the lowest ratio $(0.85)$, barley rotation the highest (1.12), and most other rotations right around $1.0(34,37,38)$.

In general, effects due to the addition of the cover crop, although significant, were minor in relation to the effects of the rotation crop itself. In previous research, crop rotation effects on soil microbial communities were also greater than those due to additions of biocontrol organisms or biological amendments (35). More diverse cropping systems have resulted in greater soil microbial biomass and FAME differences (40). In addition, it has been noted that additions of green manures often did not necessarily reduce pathogen populations or survival but did increase popula- tions of microorganisms that were antagonistic toward the pathogens $(15,51)$. Overall, our results suggest that the rotation crop is a primary determinant of the microbial community structure, shaping the microbial communities, whereas the fall cover crop can modify these communities to some degree but may have a more secondary influence relative to the summer season rotation crop effects.

In this study, reductions in soilborne disease associated with the use of cover crops were generally modest (5 to $20 \%$ ). However, the combined effects of using a cover crop in conjunction with an effective rotation crop were substantial, and greater than using either approach separately. The combination of winter rye cover crop with canola or rapeseed rotations reduced black scurf and common scab by 25 to $41 \%$ relative to a continuous potato rotation and 21 to $37 \%$ relative to the barley/clover standard rotation. In addition, it should be noted that cover crops are not only to be considered for disease management. Cover crops are generally used for the many other positive benefits they contribute to the cropping system (such as addition of organic matter, erosion control, weed control, and improvements in soil structure and tilth, nitrogen fertility, and crop productivity). Therefore, their potential for improving disease control is mainly a bonus. In the present study, only winter rye and, to a lesser extent, ryegrass, were tested as a cover crop within potato cropping systems. Further research would be appropriate to determine whether other cover crops may provide additional benefits.

Based on the results from this study, as well as our other current and previous cropping system studies (34-38), the best use of rotations for the management of diseases and sustainable potato production in the northeast should involve (i) the use of a 3-year rotation or longer; (ii) the use of a disease-suppressive rotation crop prior to potato, such as a Brassica (canola, rapeseed, mustard) crop or small grain (i.e. barley); and (iii) the use of a fall cover crop (such as winter rye or ryegrass) following both the rotation and potato crops. Effective rotations are important for reducing or minimizing potential soilborne disease problems but cannot, by themselves, completely control or eliminate diseases. Good rotation strategies should be used in conjunction with other crop and soil management approaches to achieve more sustainable crop production.

\section{ACKNOWLEDGMENTS}

We thank L. Matthiesen and M. Brewer for their thorough and capable technical assistance on all aspects of this work; D. Torrey for managing and maintaining the field sites; P. Pinette, G. Trusty, E. Mallory, E. Champaco, B. Lagasse, and D. Cowperthwaite for additional technical support, our fellow NEPSWL scientists O.M Olanya, G. Starr, J. Halloran, and Z. He, who have all contributed to this research in various ways; the many people who have worked on or contributed to this research in various ways over the years of these studies, including summer workers and student aides, field crews, technicians, colleagues, and miscellaneous hands and expertise; and all the others without whom these large, long-term studies could never be completed.

\section{LITERATURE CITED}

1. Bailey, K. L., and Lazarovits, G. 2003. Suppressing soil-borne diseases with residue management and organic amendments. Soil Till. Res. 72:169-180.

2. Ball, B. C., Bingham, I., Rees, R. M., and Watson, C. A. 2005. The role of crop rotations in determining soil structure and crop growth conditions. Can. J. Plant Sci. 85:557-577.

3. Bonanomi, G., Antignani, V., Capodilupo, M., and Scala, F. 2010. Identifying the characteristics of organic amendments that suppress soilborne plant diseases. Soil Biol. Biochem. 42:136-144.

4. Bossio, D. A., and Scow, K. M. 1998. Impacts of carbon and flooding on soil microbial communities: phospholipid fatty acid profiles and substrate utilization patterns. Microb. Ecol $35: 265$.

5. Brewer, M. T. 2003. Effects of biological control and a ryegrass rotation on Rhizoctonia disease of potato. M.S. thesis in Plant, Soil and Environmental Sciences, Department of Plant, Soil., and Environmental Sciences University of Maine, Orono.

6. Brown, P. D., and Morra, M. J. 1997. Control of soilborne plant pests using glucosinolatecontaining plants. Adv. Agron. 61:167-231.

7. Buyer, J. S., Roberts, D. P., and RusseckCohen, E. 1999. Microbial community structure and function in the spermosphere as affected by soil and seed type. Can. J. Microbiol. 45:138-144.

8. Campbell, C. L., and Madden, L. V. 1990 Introduction to Plant Disease Epidemiology. John Wiley \& Sons, New York.

9. Campiglia, E., Paolini, R., Colla, G., and Mancinelli, R. 2009. The effects of cover cropping on yield and weed control of potato in a transitional system. Field Crops Res. 112:16-23.

10. Carter, M. R., Kunelius, H. T., Sanderson, J. B., Kimpinski, J., Platt, H. W., and Bolinder M. A. 2003. Productivity parameters and soil health dynamics under long-term 2-year potato rotations in Atlantic Canada. Soil Till. Res. 72:153-168.

11. Carter, M. R., and Sanderson, J. B. 2001 Influence of conservation tillage and rotation length on potato productivity, tuber disease and soil quality parameters on a fine sandy loam in eastern Canada. Soil Till. Res. 63:113 .

12. Cohen, M. F., Mazzola, M., and Yamasaki, H. 2005. Brassica napus seed meal soil amendment modifies microbial community structure, nitric oxide production and incidence of Rhizoctonia root rot. Soil Biol. Biochem. 37:1215-1227.

13. Cook, R. J. 1986. Interrelationships of plant health and the sustainability of agriculture, with special reference to plant diseases. Am. J. Altern. Agric. 1:19-24.

14. Cook, R. J. 2000. Advances in plant health management in the twentieth century. Annu. Rev. Phytopathol. 38:95-116.

15. Davis, J. R., Huisman, O. C., Westermann, D. T., Hafez, S. L., Everson, D. O., Sorensen, L. H., and Schneider, A. T. 1996. Effects of green manures on Verticillium wilt of potato. Phytopathology 86:444-453.

16. Fageria, N. K., Baligar, V. C., and Bailey, B. A 2005. Role of cover crops in improving soi and row crop productivity. Commun. Soil Sci. Plant 36:2733-2757.

17. Friberg, H., Edel-Hermann, V., Faivre, C. Gautheron, N., Fayolle, L., Faloya, V., Mont- 
fort, F., and Steinberg, C. 2009. Cause and duration of mustard incorporation effects on soilborne plant pathogenic fungi. Soil Biol. Biochem. 41:2075-2084.

18. Garbeva, P., van Veen, J. A., and van Elsas, J. D. 2004. Microbial diversity in soil: selection of microbial populations by plant and soil type and implications for disease suppressiveness. Annu. Rev. Phytopathol. 42:243-270.

19. Garland, J. L., and Mills, A. L. 1991. Classification and characterization of heterotrophic microbial communities on the basis of patterns of community-level sole-carbon-source utilization Appl. Environ. Microbiol. 57:2351-2359.

20. Ghorbani, R., Wilockson, S., Koocheki, A., and Leifert, C. 2008. Soil management for sustainable crop disease control: a review. Environ. Chem. Lett. 6:149-162.

21. Glimm, E., Heuer, H., Engelen, B., Smalla, K., and Backhaus, H. 1997. Statistical comparisons of community catabolic profiles. J. Microbiol. Methods 30:71-80.

22. Grandy, A. S., Porter, G. A., and Erich, M. S. 2002. Organic amendment and rotation crop effects on the recovery of soil organic matter and aggregation in potato cropping systems. Soil Sci. Soc. Am. J. 66:1311-1319.

23. Grayston, S. J., Wang, S., Campbell, C. D., and Edwards, A. C. 1998. Selecting influence of plant species on microbial diversity in the rhizosphere. Soil Biol. Biochem. 30:369-378.

24. Griffin, T. S., Larkin, R. P., and Honeycutt, C. W. 2009. Delayed tillage and cover crop effects in potato systems. Am. J. Potato Res. 86:79-87.

25. Hide, G. A., and Read, P. J. 1991. Effects of rotation length, fungicide treatment of seed tubers and nematicide on diseases and the quality of potato tubers. Ann. Appl. Biol. 119:77-87.

26. Hoekstra, O. 1989. Results of twenty-four years of crop rotation research at 'De Schreef' experimental site. In: Effects of Crop Rotation on Potato Production in the Temperate Zones. J. Vos, C. D. van Loon, and G. J. Bollen, eds. Kluwer Academic Publishers, Dordrecht, The Netherlands.

27. Honeycutt, C. W., Clapham, W. M., and Leach, S. S. 1996. Crop rotation and $\mathrm{N}$ fertilization effects on growth, yield., and disease incidence in potato. Am. Potato J. 73:45-61.

28. Janvier, C., Villeneuve, F., Alabouvette, A., Edel-Hermann, V., Mateille, T., and Steinberg, C. 2007. Soil health through soil disease suppression: which strategy from descriptors to indicators? Soil Biol. Biochem. 39:1-23.

29. Johnston, H. W., Celetti, M. J., Kimpinski, J., and Platt, H. W. 1994. Fungal pathogens and Pratylenchus penetrans associated with preceding crops of clovers, winter wheat., and annual ryegrass and their influence on succeeding potato crops on Prince Edward Island. Am. Potato J. 71:797-808.

30. Kabir, Z., Bhat, G., and Subbarao, K. V. 2004. Comparison of media for recovery of Verticillium dahliae from soil. Plant Dis. 88:49-55.

31. Karlen, D. L., Hurley, E. G., Andrews, S. S., Cambardella, C. A., Meek, D. W., Duffy, M. D., and Mallarino, A. P. 2006. Crop rotation effects on soil quality at three northern corn/soybean belt locations. Agron. J. 98:484-495.

32. Krupinsky, J. M., Bailey, K. L., McMullen, M. M., Gossen, B. D., and Turkington, T. K. 2002. Managing plant disease risk in diversified cropping systems. Agron. J. 94:198-209.

33. Ladygina, N., and Hedlund, K. 2010. Plant species influence microbial diversity and carbon allocation in the rhizosphere. Soil Biol. Biochem. 42:162-168.

34. Larkin, R. P. 2003. Characterization of soil microbial communities under different potato cropping systems by microbial population dy- namics, substrate utilization, and fatty acid profiles. Soil Biol. Biochem. 35:1451-1466.

35. Larkin, R. P. 2008. Relative effects of biological amendments and crop rotations on soil microbial communities and soilborne diseases of potato. Soil Biol. Biochem. 40:1341-1351.

36. Larkin, R. P., and Griffin, T. S. 2007. Control of soilborne diseases of potato using Brassica green manures. Crop Prot. 26:1067-1077.

37. Larkin, R. P., and Honeycutt, C. W. 2006. Effects of different 3-year cropping systems on soil microbial communities and Rhizoctonia diseases of potato. Phytopathology 96:68-79.

38. Larkin, R. P., Honeycutt, C. W., Griffin, T. S., Olanya, O. M., Halloran, J. M., and He, Z. Effects of different potato cropping system approaches and water management on soilborne diseases and soil microbial communities. Phytopathology. In Press.

39. Larkin, R. P., Hopkins, D. L., and Martin, F. N. 1993. Ecology of Fusarium oxysporum f. sp. niveum in soils suppressive and conducive to Fusarium wilt of watermelon. Phytopathology 83:1105-1116.

40. Leibig, M., Carpenter-Boggs, L., Johnson, J. M. F., Wright, S., and Barbour, N. 2006. Cropping system effects on soil biological characteristics in the Great Plains. Renew. Agric. Food Syst. 21:36-48.

41. Lupawayi, N. Z., Rice, W. A., and Clayton, G. W. 1998. Soil microbial diversity and community structure under wheat as influenced by tillage and crop rotation. Soil Biol. Biochem. 30:1733-1741.

42. Magdoff, F. 2000. Concepts, components, and strategies of soil health in agroecosystems. J. Nematol. 33:169-172.

43. Magdoff, F., and van Es, H. 2000. Cover crops and Crop rotations. In: Building Soils for Better Crops. Sustainable Agriculture Publications, University of Vermont, Burlington.

44. Manici, L. M., and Caputo, F. 2009. Fungal community diversity and soil health in intensive potato cropping systems of the east Po valley, northern Italy. Ann. Appl. Biol. 155:245-258.

45. Matthiessen, J. N., and Kirkegaard, J. A. 2006. Biofumigation and enhanced biodegradation: opportunity and challenge in soilborne pest and disease management. Crit. Rev. Plant Sci. 25:235-265.

46. Mazzola, M. 2004. Assessment and management of soil microbial community structure for disease suppression. Annu. Rev. Phytopathol. 42:35-59.

47. Mazzola, M., Granatstein, D. M., Elfving, D. C., and Mullinix, K. 2001. Suppression of specific apple root pathogens by Brassica napus seed meal amendment regardless of glucosinolate content. Phytopathology 91:673-679.

48. McGuire, A. N. 2003. Mustard green manures replace fumigant and improve infiltration in potato cropping system. Crop Manage. Online. doi: 10.1094/CM-2003-0822-01-RS

49. Morrison, J. E., Jr., Lemunyon, J., and Bogusch, H. C., Jr. 1995. Sources of variation and performance of nine devices when measuring percent residue covers. Trans. ASAE 38:521529.

50. O'Donnell, A. G., Seasman, M., MacRae, A., Waite, I., and Davies, J. T. 2001. Plants and fertilisers as drivers of change in microbial community structure and function in soils. Plant Soil 232:135-145.

51. Perez, C., Dill-Macky, R., and Kinkel, L. L. 2008. Management of soil microbial communities to enhance populations of Fusarium graminearum-antagonists in soil. Plant Soil 302:53-69.

52. Peters, R. D., Sturz, A. V., Carter, M. R., and Sanderson, J. B. 2003. Developing disease- suppressive soils through crop rotation and tillage management practices. Soil Till. Res. 72:181-192.

53. Peters, R. D., Sturz, A. V., Carter, M. R., and Sanderson, J. B. 2004. Influence of crop rotation and conservation tillage practices on the severity of soil-borne potato diseases in temperate humid agriculture. Can. J. Soil Sci. 84:397-402.

54. Ryan, P. R., Dessaux, Y., Thomashow, L. S., and Weller, D. M. 2009. Rhizosphere engineering and management for sustainable agriculture. Plant Soil 321:363-383.

55. Sarrantonio, M., and Gallandt, E. 2003. The role of cover crops in North American cropping systems. J. Crop Prod. 8:53-74.

56. Sarwar, M., Kirkegaard, J. A., Wong, P. T. W. and Desmarchelier, J. M. 1998. Biofumigation potential of Brassicas. III. In vitro toxicity of isothiocyanates to soil-borne fungal pathogens. Plant Soil 210:103-112.

57. Smolinska, U., and Horbowicz, M. 1999 Fungicidal activity of volatiles from selected cruciferous plants against resting propagules of soil-borne fungal pathogens. J. Phytopathol 147:119-124.

58. Snapp, S. S., Date, K. U., Kirk, W., O'Neill, K., Kremen, A., and Bird, G. 2007. Root, shoot tissues of Brassica juncea and Cereal secale promote potato health. Plant Soil 294:55-72.

59. Snapp, S. S., Swinton, S. M., Labarta, R. Mutch, D., Black, J. R., Leep, R., Nyiraneza, J., and O'Neil, K. 2005. Evaluating cover crops for benefits, costs, and performance within cropping system niches. Agron. J. 97:322-332.

60. Specht, L. P., and Leach, S. S. 1987. Effects of crop rotation on Rhizoctonia disease of white potato. Plant Dis. 71:433-437.

61. Stevenson, W. R. 2001. Compendium of Potato Diseases. 2nd ed. American Phytopathological Society, St. Paul, MN

62. Sturz, A. V., and Christie, B. R. 2003. Beneficial microbial allelopathies in the root zone the management of soil quality and plant disease with rhizobacteria. Soil Till. Res. 72:107 123.

63. Sturz, A. V., Christie, B. R., and Matheson, B. G. 1998. Associations of bacterial endophyte populations from red clover and potato crops with potential for beneficial allelopathy. Can J. Microbiol. 44:162-167.

64. Thorup-Kristensen, K., Magid, J., and Jensen, L. S. 2003. Catch crops and green manures as biological tools in nitrogen management in temperate zones. Adv. Agron. 79:227-302.

65. Van Elsas, J. D., Garbeva, P., and Salles, J. 2002. Effects of agronomical measures on the microbial diversity of soils as related to the suppression of soil-borne plant pathogens. Biodegradation 13:29-40.

66. Vepsalainen, M., Erkomaa, K., Kukkonen, S. Vestberg, M., Wallenius, K., and Niemi, R. M. 2004. The impact of crop plant cultivation and peat amendment on soil microbial activity and structure. Plant Soil 264:273.

67. Welbaum, G. E., Sturz, A. V., Dong, Z., and Nowak, J. 2004. Managing soil microorganisms to improve productivity of agroecosystems. Crit. Rev. Plant Sci. 23:175-193.

68. Wiggins, B. E., and Kinkel, L. L. 2005. Green manures and crop sequences influence potato diseases and pathogen inhibitory activity of indigenous streptomycetes. Phytopathology 95:178-185.

69. Zelles, L., Bai, Q. Y., Rackwitz, R., Chadwick, D., and Beese, F. 1995. Determination of phospholipid- and lipopolysaccharide-derived fatty acids as an estimate of microbial biomas and community structures in soils. Biol. Fertil. Soils 19:115-123. 